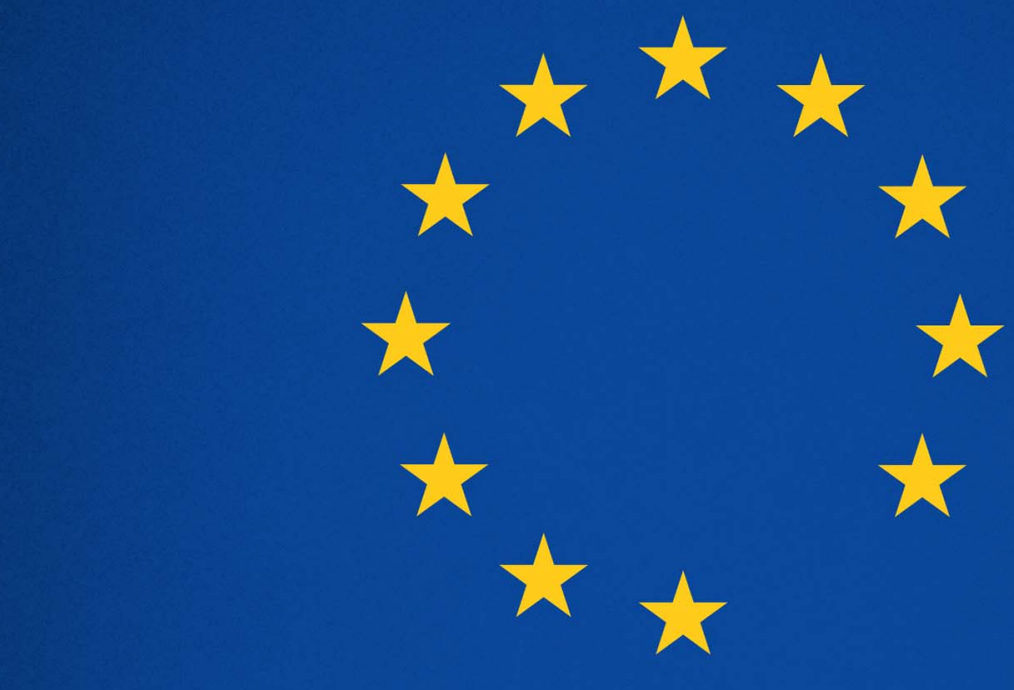

\title{
The European Union after Brexit
}

EDITED BY SCOTT L. GREER AND JANET LAIBLE 


\section{The European Union after Brexit}

\section{MANCHESTER 1824}

Manchester University Press 
Scott L. Greer and Janet Laible - 9781526133663 Downloaded from manchesterhive.com at 04/26/2023 03:15:39PM via free access 


\section{The European Union after Brexit}

Edited by Scott L. Greer and Janet Laible

Manchester University Press 
Copyright (C) Manchester University Press 2020

While copyright in the volume as a whole is vested in Manchester University Press, copyright in individual chapters belongs to their respective authors, and no chapter may be reproduced wholly or in part without the express permission in writing of both author and publisher.

Published by Manchester University Press

Altrincham Street, Manchester M1 7JA

www.manchesteruniversitypress.co.uk

British Library Cataloguing-in-Publication Data

A catalogue record for this book is available from the British Library

ISBN 9781526133656 hardback

First published 2020

The publisher has no responsibility for the persistence or accuracy of URLs for any external or third-party internet websites referred to in this book, and does not guarantee that any content on such websites is, or will remain, accurate or appropriate.

Typeset by

Servis Filmsetting Ltd, Stockport, Cheshire 